\title{
Pemberdayaan UMKM Sepatu dengan Aplikasi E- Commerce sebagai Pendukung Pemasaran saat Pandemi Covid-19
}

\author{
Tri Ika Jaya Kusumawati ${ }^{{ }^{*}}$, Teja Endra Eng Tju ${ }^{2}$, Ravindra Safitra Hidayat ${ }^{3}$ \\ 1, 2,3, Universitas Budi Luhur \\ ${ }^{1}$ tri.ikajaya@budiluhur.ac.id, ${ }^{2}$ teja.endraengtju@budiluhur.ac.id, ${ }^{3}$ ravindra.safitra@budiluhur.ac.id
}

\begin{abstract}
Abstrak
UMKM Istiana Sepatu merupakan salah satu UMKM yang dalam masa pandemi ini menghadapi masalah yaitu sulitnya melakukan penjualan dan pemasaran, dikarenakan pembatasan dan penutupan kios oleh pemerintah daerah. Akibat yang sangat dirasakan yaitu penumpukan barang yang tidak laku. Berdasarkan masalah tersebut kegiatan pengabdian kepada masyarakat ini menawarkan solusi berupa perbaikan proses yang ada dan pembuatan proses baru yang diterapkan pada sistem e-commerce berbasis web dengan CMS WordPress. Usulan proses pemasaran, pemesanan, pembayaran, pengiriman, dan pelaporan telah dibuat dan diimplementasi sehingga memberikan manfaat kepada UMKM Istiana Sepatu yaitu: adanya informasi yang lebih cepat dan akurat bagi pembeli dan pegawai dalam hal harga dan rincian produk; sinkronnya pencatatan dalam transaksi penjualan dan persediaan yang ada di toko; meminimalisasi terjadinya kesalahan harga dan perhitungan antara transaksi penjualan dan pembayaran; serta proses perhitungan dan pelaporan transaksi penjualan dapat dilakukan dengan waktu yang lebih cepat. Dengan adanya kebijakan PSBB dari pemerintah yang berkelanjutan, pengunjung toko sangat sedikit karena mereka lebih memilih tinggal di rumah sehingga menyebabkan kedua toko Istiana Sepatu sering tutup. Namun dalam masa pandemi, Istiana Sepatu masih bisa berjualan melalui e-commerce yang baru dibuat sehingga jangkauan pemasaran lebih luas dan eksis. Berdasarkan hasil yang dibuat telah dilakukan penilaian dari user menggunakan usability testing sederhana pada web ecommerce yang dibangun; Learnability diperoleh nilai rata-rata 78,97\%; Efficiency diperoleh nilai rata-rata $71,28 \%$; Memorability diperoleh nilai rata-rata $82,1 \%$; Error diperoleh nilai rata-rata $85,7 \%$; Satisfaction diperoleh nilai rata-rata $80,77 \%$. Secara kesuluruhan nilai penerimaan user terhadap sistem e-commerce yang dibangun didapat nilai rata-rata $79,77 \%$. Angka ini menunjukkan bahwa aplikasi atau sistem yang dibangun dapat diterima dengan baik dan berhasil memenuhi aspek usability system.
\end{abstract}

Kata Kunci: E-Commerce, CMS, Covid, UMKM

\section{Pendahuluan}

Perkembangan UMKM (Usaha Mikro, Kecil, dan Menengah) semakin pesat sejalan dengan kemajuan Internet. Transaksi jual beli produk digital ataupun barang dan jasa bisa dilakukan secara cepat, murah, dan mudah dengan adanya sistem e-commerce (Setiawan, D. et al., 2018). Bidang usaha fashion yang juga berkembang adalah sepatu dan 
sandal, menjadi trend di kalangan masyarakat sehingga banyak persaingan. Pengembangan website sangat penting untuk mengatasi persaingan bisnis penjualan sepatu, dalam melakukan kegiatan transaksi mulai dari proses order, menyimpan data produk, mengubah data produk serta menghapus data produk sehingga menghasilkan informasi yang cepat, tepat, akurat dan menarik bagi pelanggan (Lesmono, I.D., 2018). Sepanjang tahun 2018 industri alas kaki Indonesia mencatatkan jumlah produksinya mencapai 1,41 miliar pasang sepatu atau berkontribusi 4,6 persen dari total produksi sepatu dunia (Jannah, S.M., 2019).

Dengan permasalahan di atas maka dipilihlah UMKM Istiana Sepatu untuk diberdayakan dalam hal penjualan dan pemasaran, terutama di masa pandemi Covid-19. Istiana Sepatu adalah sebuah toko sepatu yang didirikan oleh Nur Istiana pada tahun 2009. Toko ini berfokus pada penjualan sandal dan sepatu. Istiana Sepatu memiliki dua buah toko offline yang berada di kawasan Blok M Square Blok B No 289 (Gambar 1) dan di Jl. H. Aom No 96 (Gambar 2), keduanya di Jakarta Selatan.

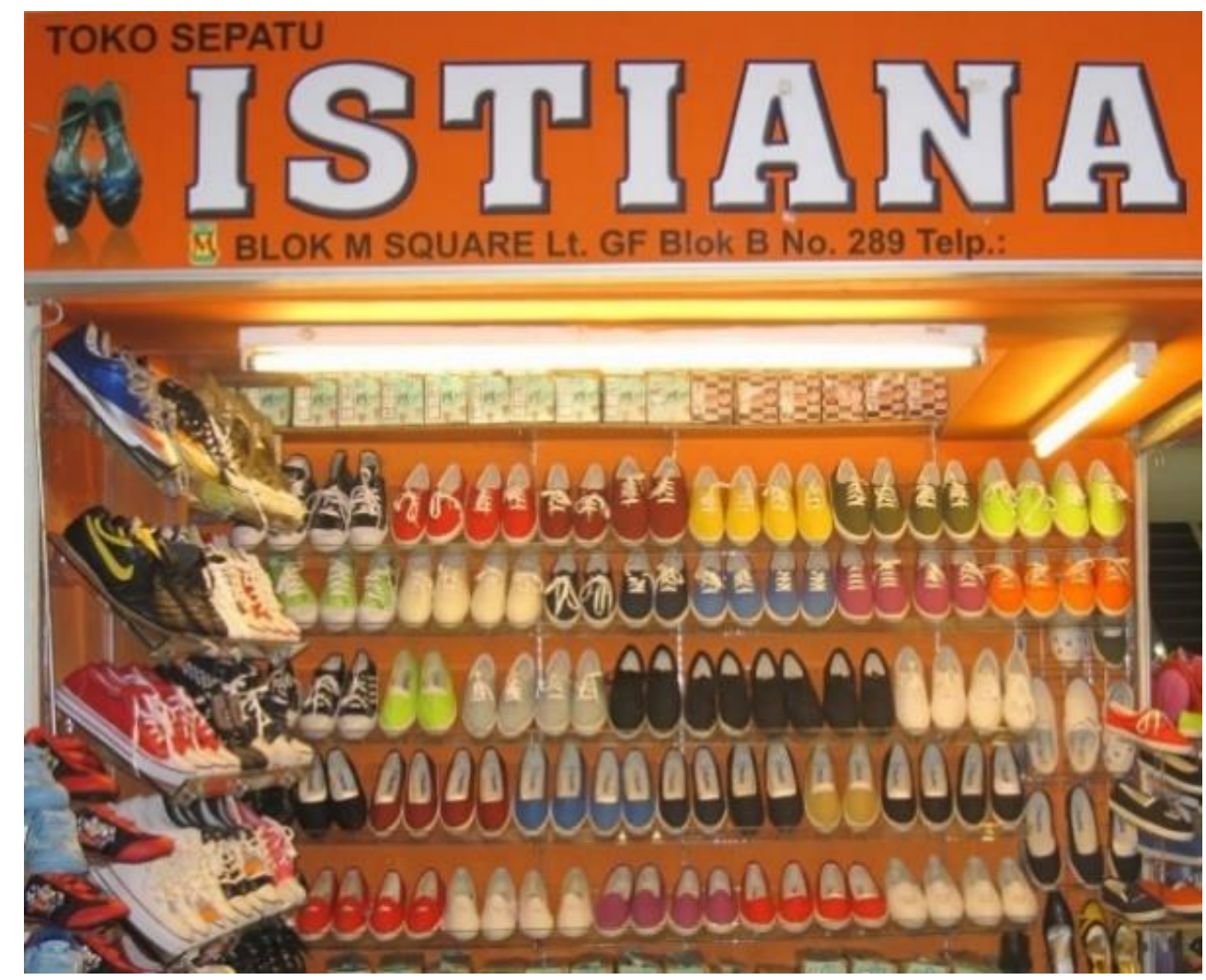

Gambar 1. Istiana Sepatu di Blok M Square. 


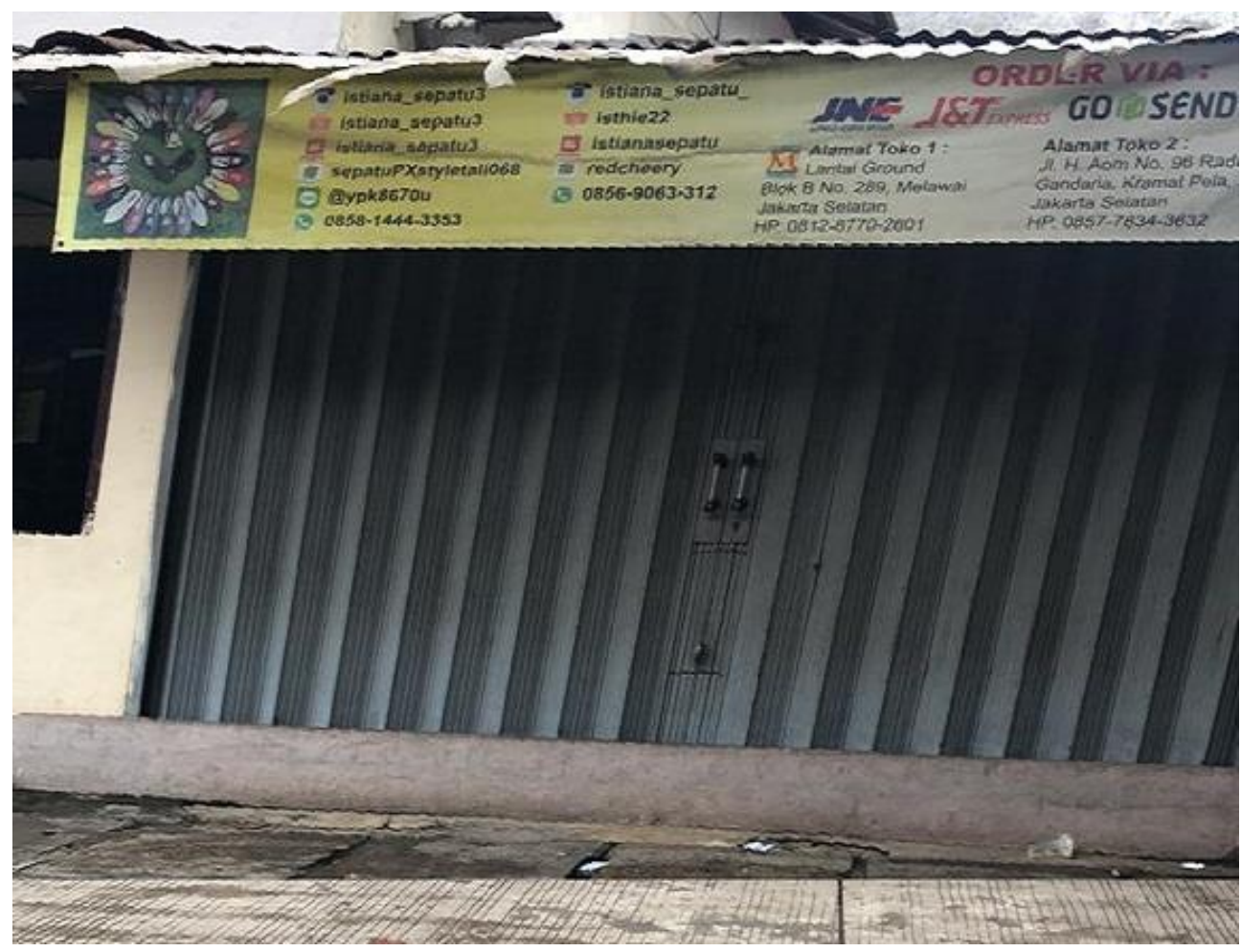

Gambar 2. Istiana Sepatu di H. Aom.

Proses kegiatan Istiana Sepatu saat ini dilakukan secara manual dan terdiri dari proses pemasaran, penjualan, pembayaran, pengiriman, dan pelaporan. Pemasaran dilakukan di toko dan melalui media sosial yang buka setiap hari dari senin sampai minggu dengan jam operasional 09.00 - 21.00 WIB. Penjualan dilakukan melalui toko dan media sosial Instagram dengan komunikasi melalui Whatsapp. Pembayaran langsung di toko bagi pengunjung atau melalui transfer jika melalui Instagram. Pengiriman barang dilakukan untuk pembelian melalui Instagram dengan menggunakan jasa kurir. Setiap akhir bulan pegawai toko dan administrasi akan membuat laporan penjualan berdasarkan nota pembayaran dan rekapan bukti transfer pembayaran yang kemudian akan diserahkan kepada pemilik toko.

Adanya pandemi Covid-19, toko Istiana Sepatu sering tutup karena adanya peraturan pemerintah untuk mencegah penyebaran virus, selain itu pengunjung toko sangat sedikit, karena mereka lebih memilih atau terpaksa harus tinggal di rumah, bekerja dari rumah, belajar dari rumah, berdoa dari rumah. Ada suatu solusi yang bisa membawa pengaruh besar dibandingkan yang lain, yaitu membawa UMKM untuk beralih ke sektor digital (Putri, T.M., 2020).

Setelah melakukan analisa terhadap proses kegiatan yang sudah berjalan, solusi secara komprehensif ditawarkan kepada Istiana Sepatu. Solusi berupa perbaikan proses yang ada dan pembuatan proses baru yang diterapkan secara digital pada sistem ecommerce berbasis web dengan CMS (Content Management System) WordPress. Berikut ini adalah proses-proses yang diusulkan:

1. Proses Pemasaran

2. Proses Pemesanan

3. Proses Pembayaran 
4. Proses Pengiriman

5. Proses Pelaporan

Dengan solusi yang diuraikan di atas, Istiana Sepatu diharapkan terhindar dari masalah yang dihadapi dengan mendapatkan manfaat sebagai berikut:

1. Adanya informasi yang lebih cepat dan akurat bagi pembeli dan pegawai dalam hal harga, sediaan, rincian produk.

2. Sinkronnya pencatatan dalam transaksi penjualan dan persediaan yang ada di toko.

3. Meminimalisasi terjadinya kesalahan harga dan perhitungan antara transaksi penjualan dan pembayaran.

4. Proses perhitungan dan pelaporan transaksi penjualan dapat dilakukan dengan waktu yang lebih cepat.

5. Memiliki situs e-commerce sehingga jangkauan pemasaran Istiana Sepatu lebih luas dan eksis.

\section{Metode Pelaksanaan}

Pelaksanaan pemberdayaan masyarakat ini dalam periode April-Agustus 2020, sebagian besar kegiatan berupa perancangan dan pembangunan sistem dilakukan di kampus Universitas Budi Luhur dan implementasi sistem dilaksanakan di lokasi Istiana Sepatu. Pada Gambar 3 ditunjukkan peta lokasi kegiatan.

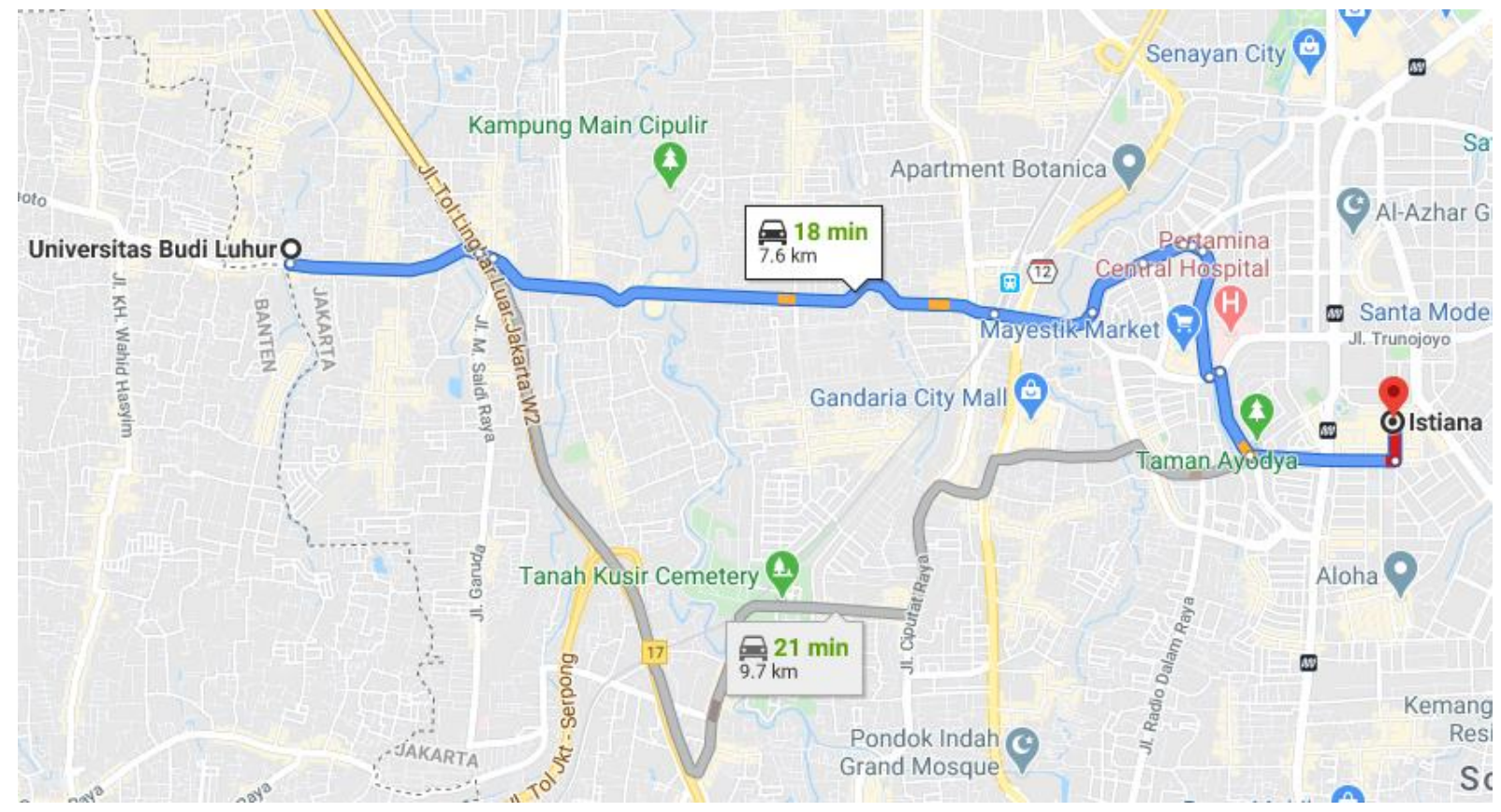

Gambar 3. Lokasi Kegiatan.

Mitra UMKM Istiana sepatu dipilih sebagai sasaran kegiatan berdasarkan informasi atau referensi dari teman sejawat yang sudah terlebih dahulu mengenal dan mengetahui kondisinya.

Tahapan atau langkah-langkah dalam melaksanakan solusi yang ditawarkan untuk mengatasi persoalan dan masalah mitra, disajikan pada Gambar 4. 


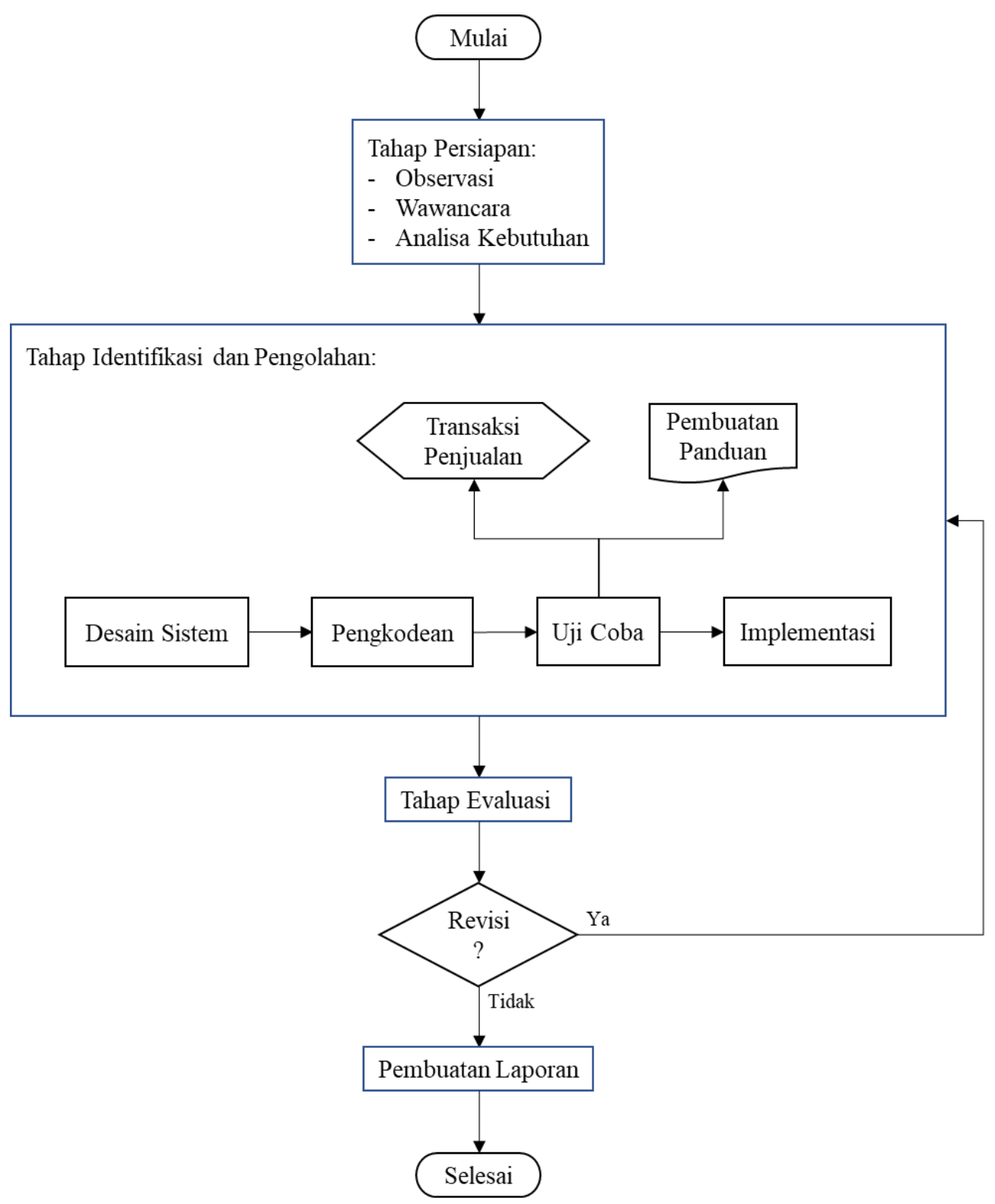

Gambar 4. Langkah Pelaksanaan

Berikut ini merupakan langkah-langkah yang dilakukan dalam kegiatan ini:

1. Tahap Persiapan, tahapan ini terdiri dari:

a. Observasi di tempat mitra;

b. Wawancara kepada mitra untuk menemukan masalah yang ingin diselesaikan;

c. Analisa kebutuhan yang dilakukan setelah observasi dan wawancara untuk menentukan kebutuhan system.

2. Tahap identifikasi dan pengolahan, tahapan ini terdiri dari:

a. Desain, tahapan perancangan sistem yang diusulkan;

b. Pengkodean, tahapan pembuatan sistem sesuai desain;

c. Uji coba sistem, tahapan pemeriksaan berjalannya sistem pada dua kegiatan utama yaitu jual/beli dan pembuatan panduan penggunaan;

d. Implementasi, tahapan instalasi sistem untuk mitra. 
3. Tahap evaluasi, merupakan tahapan feedback dari mitra pada hasil implementasi sistem dengan memberikan kuesioner kepuasan pengguna terhadap sistem yang dibangun.

4. Tahap pembuatan laporan, setelah semua tahapan disetujui maka dilakukan serah terima dan dilanjutkan pembuatan laporan dan publikasi kegiatan.

Hasil pembuatan sistem e-commerce berbasis web dengan CMS (Content Management System) WordPress disimpan dan digunakan oleh Istiana Sepatu pada laptop dengan spesifikasi sebagai berikut:

1. Perangkat Keras

$$
\begin{array}{ll}
\text { - } & \text { Hard Disk } \\
\text { - } & \text { Processor } \\
\text { - } & \text { RAM } \\
\text { - VGA }
\end{array}
$$

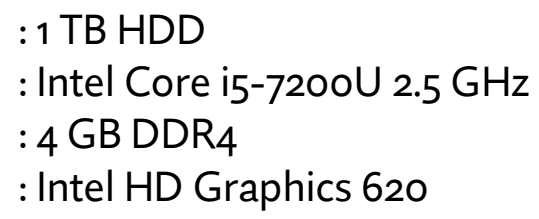

2. Perangkat Lunak

- Operating System : Windows 8

- Office Applications : Microsoft Office 2010

- Browser : Google Chrome

Indikator keberhasilan dari kegiatan ini adalah Istiana Sepatu tetap bisa melakukan proses penjualan dan pemasaran sehingga tetap eksis di masa pandemi dan semakin terkenal pada saat toko bisa beroperasional lagi.

Metode evaluasi digunakan usability testing sederhana untuk hasil web e-commerce yang dibangun. Penilaian meliputi learnability, efficiency, memorability, error, dan satisfaction, dengan nilai masing-masing di atas $50 \%$ dan total penilaian bisa mencapai $70 \%$.

\section{Hasil dan Pembahasan}

Situs e-commerce Istiana Sepatu telah dilakukan hosting dan dapat diakes pada https://istianasepatu.com. Secara komprehensif mencakup proses-proses pemasaran, pemesanan, pembayaran, pengiriman, dan pelaporan. Istiana Sepatu sangat terbantu dalam hal: memberikan informasi yang lebih cepat dan akurat bagi pembeli dan pegawai dalam hal harga, sediaan, rincian produk; sinkronnya pencatatan dalam transaksi penjualan dan persediaan yang ada di toko; minim terjadinya kesalahan harga dan perhitungan antara transaksi penjualan dan pembayaran; proses perhitungan dan pelaporan transaksi penjualan dapat dilakukan dengan waktu yang lebih cepat; serta memiliki situs e-commerce sehingga jangkauan pemasaran Istiana Sepatu lebih luas dan eksis.

Satu hal yang sangat disyukuri oleh Istiana Sepatu dalam masa pandemik virus Covid19 masih bisa berjualan dengan e-commerce yang baru dibuat. Dengan adanya kebijakan PSBB (Pembatasan Sosial Berskala Besar) dari pemerintah yang berkelanjutan, menyebabkan kedua toko Istiana Sepatu sering tutup, selain itu pengunjung toko sangat sedikit, karena mereka lebih memilih tinggal di rumah, bekerja dari rumah, belajar dari rumah, berdoa dari rumah, dan belanja sepatu dari rumah juga. 
Gambar 5 merupakan tampilan halaman utama dari aplikasi atau sistem e-commerce yang dibangun. Halaman ini merupakan halaman utama user untuk melihat produk dan bertransaksi. Terdapat menu dan fitur untuk mempermudah user/calon pembeli.

Berdasarkan hasil yang telah dibuat untuk mitra, diajukan beberapa pertanyaan penilaian terhadap mitra menggunakan usability testing sederhana untuk hasil web ecommerce yang dibangun.

1. Learnability

Berdasarkan kemudahan penggunaan didapatkan nilai rata-rata 78,97\%.

2. Efficiency

Berdasarkan kecepatan user dalam mengunakan sistem didapatkan nilai rata-rata $71,28 \%$

3. Memorability

Berdasarkan ingatan user dalam langkah-langkah penggunaan sistem didapatkan nilai rata-rata $82,1 \%$.

4. Error

Berdasarkan banyaknya user melakukan kesalahan dan memperbaikinya didapatkan nilai rata-rata $85,7 \%$

5. Satisfaction

Berdasarkan bagaimana perasaan user ketika mengunakan system yang ada didapatkan nilai rata-rata $80,77 \%$

Secara kesuluruhan nilai penerimaan user terhadap sistem e-commerce yang dibangun didapat nilai $79,77 \%$. Angka ini menunjukkan bahwa aplikasi atau sistem yang dibangun dapat diterima dengan baik dan berhasil memenuhi aspek usability system. 

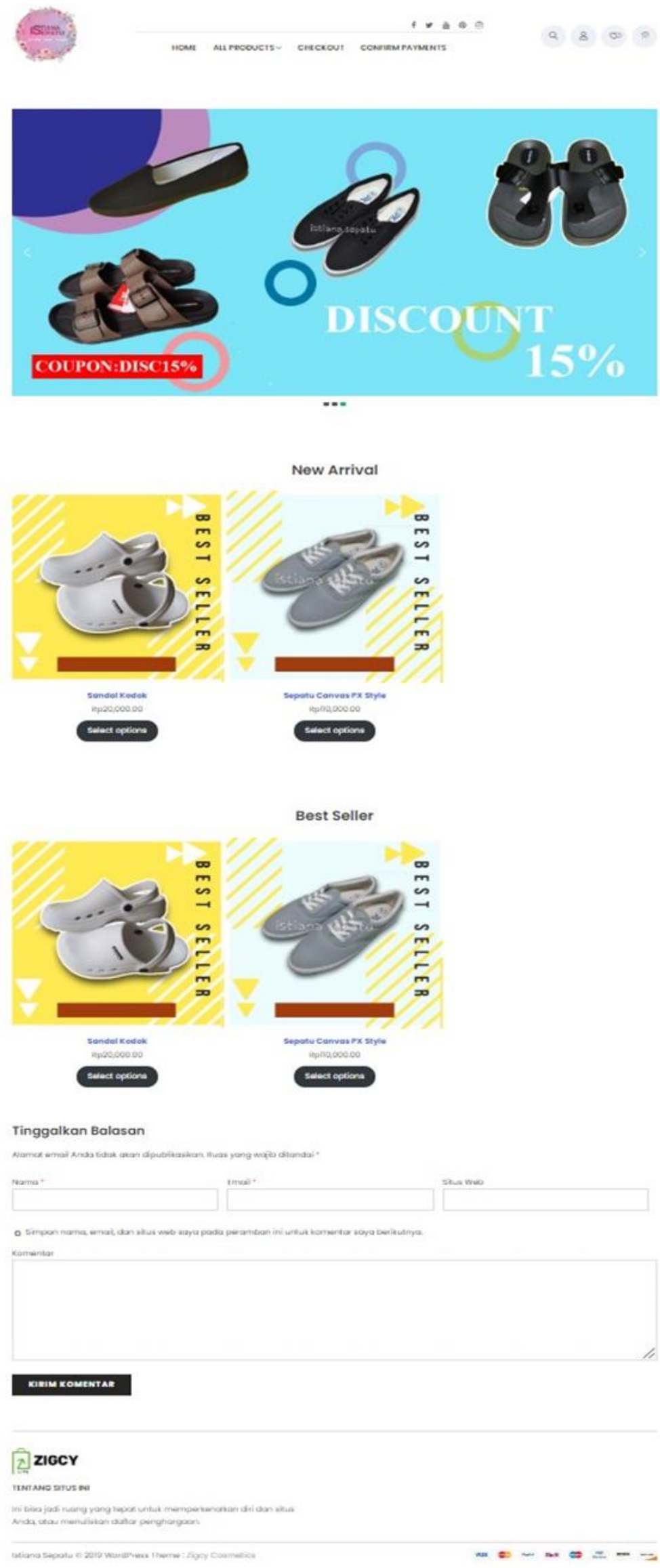

Gambar 5. Tampilan Utama Sistem 


\section{Kesimpulan}

Setelah dilakukan kegiatan pengabdian kepada masyarakat ini dalam rangka membangun sebuah website penjualan dan pemasaran pada Istiana Sepatu, maka telah berhasil mengatasi masalah-masalah yang sebelumnya dilakukan secara manual, sekarang telah terotomatisasi. Terlebih lagi dengan adanya pandemik COVID-19, Istiana Sepatu masih bisa berjualan dengan e-commerce yang telah dibuat. Dalam kondisi kedua toko Istiana Sepatu sering tutup, selain itu pengunjung toko sangat sedikit, karena mereka lebih memilih tinggal di rumah, bekerja dari rumah, belajar dari rumah, berdoa dari rumah, namun masih bisa beli sepatu dengan mengakses https://istianasepatu.com. Secara kesuluruhan nilai penerimaan user terhadap sistem e-commerce yang dibangun didapat nilai $79,77 \%$. Angka ini menunjukkan bahwa aplikasi atau sistem yang dibangun dapat diterima dengan baik dan berhasil memenuhi aspek usability system. Hal-hal tersebut di atas menunjukkan bahwa website yang dibangun cukup memuaskan dan sesuai dengan kebutuhan bagi pemilik UMKM Istiana Sepatu.

Saran untuk pengabdian berikutnya dengan memberikan pelatihan dan pendampingan kepada karyawannya secara intensif, sosialiasi website terkait dengan peningkatan SEO (Search Engine Optimization) agar lebih dikenal luas dan optimal dalam pemasaran dan penjualan.

\section{Ucapan Terimakasih}

Kami ucapkan terimakasih kepada DRPM Universitas Budi Luhur dan Yayasan pendidikan Budi Luhur Cakti yang telah memberikan dukungan berupa pembiayaan terhadap kegiatan Pengabdian Kepada Masyarakat yang dituangkan dalam jurnal ini.

\section{Referensi}

Jannah, S. M. (2019). Indonesia Produksi 4,6 Persen dari Total Sepatu Dunia. Available at: https://tirto.id/indonesia-produksi-46-persen-dari-total-sepatu-dunia-dlwU

Lesmono, I. D. (2018). Rancang Bangun Sistem Informasi Penjualan Sepatu Berbasis Website dengan Metode Waterfall. Jurnal Swabumi, 6(1), 55-62.

Luhur, U. B. (2020). Rencana Strategis Universitas Budi Luhur 2020. Available at: http://www.budiluhur.ac.id/tentang-ubl/visi-dan-misi/

Putri, T. M. (2020). Permasalahan UMKM di Masa Pandemi Covid-19. Available at: Permasalahan UMKM di Masa Pandemi Covid-19 Halaman all - Kompasiana.com.

Setiawan, D., \& Lutfi, L. (2018). Analisis dan Perancangan Sistem Informasi e-Commerce Berbasis Web pada UMKM Batik Rindani Jambi. Jurnal Sains Sosio Humaniora, 2(1), 69-78. https://doi.org/10.22437/jssh.v2i1.5283 